\title{
SKUTKI SIEROCTWA DZIECKA W WYMIARZE SPOLECZNYM, MORALNYM I OSOBOWOŚCIOWYM W WYNIKU EMIGRACJI RODZICÓW
}

\begin{abstract}
Streszczenie
W dzisiejszym świecie podkreśla się, że człowiek nie ma żadnych barier w przemieszczaniu się z miejsca na miejsce. Emigrując ze swego kraju dokonuje tego głównie z pobudek ekonomicznych. Pragnie szybko zdobyć środki materialne i uposażyć własną rodzinę. Niestety, wielokrotnie nie dostrzega, że jego wyjazd wywołuje określone konsekwencje. W szczególny sposób dotykają one dziecka, które dzisiaj określane jest jako eurosierota. Pozostawione sobie, a wręcz porzucone przez swoich opiekunów na swój sposób poszukuje zapełnienia pustki rodzicielskiej miłości. Znajduję ją w wielu uzależnieniach i dewiacjach seksualnych.
\end{abstract}

Słowa kluczowe: sierota, eurosierota, dziecko, rodzina

Wstęp

W dzisiejszym świecie człowiek odczuwa wielkie poczucie własnej niezależności, a jednocześnie przynależności do wielkiej rodziny europejskiej. Dzieje się tak, ponieważ może bardzo szybko bez jakichkolwiek problemów przekraczać granice państw i znajdować w nich zatrudnienie. Emigruje do innych krajów z różnych powodów. Jednym z nich jest chęć poprawy kondycji ekonomicznej własnej rodziny. Niestety, dokonując takiego wyboru niejako na pastwę losu zostawia swoich najbliższych, w tym własne dzieci. Zbyt duża odległość do miejsca zamieszkania członków rodziny prowadzi do rozluźnienia więzi emocjonalnych między nimi. Pojawiają się problemy, które dotykają dorastające dzieci. Rozłąka z jednym lub 
dwoma rodzicami powoduje często nieodwracalne skutki w wymiarze społecznym, moralnym i osobowościowym dziecka. Celem niniejszego opracowania jest zwrócenie uwagi na nowe zjawisko sieroctwa i jego skutki społeczne, osobowościowe i moralne.

\section{Etiologia sieroctwa i eurosieroctwa}

Słowo sieroctwo odnosi się do dziecka, które zostało pozbawione rodziców (por Matyjas, 2006, s. 725). Barbara Czeredrecka wyróżnia trzy rodzaje sieroctwa: naturalne, społeczne i duchowe. Naturalne spowodowane jest brakiem biologicznych rodziców wskutek ich śmierci. Ma charakter trwały, ponieważ niemożliwe jest przywrócenie dziecku nieżyjących opiekunów (1998, s. 44).

Sieroctwo emocjonalne, czyli duchowe, to zjawisko subiektywne i występuje jako wewnętrzne poczucie izolacji emocjonalnej w rodzinie. Rodzi się w wyniku zawężenia funkcji opiekuńczo-wychowawczej i rozbicia więzi uczuciowo-rodzinnej, dystansu emocjonalnego i obojętności rodziców. Dziecko z takiej rodziny ma poczucie samotności i opuszczenia. Zanika potrzeba miłości i psychicznego zrozumienia. Powstałe na tym gruncie patologie mają swoje odbicie w jakości wychowywania dziecka, które pozostawione samo sobie nie potrafi poradzić sobie z narastającymi problemami. Czuje się zagubione i nieszczęśliwe (Kawula, Brągiel, Janke, 1995, s. 57-58).

Z kolei sieroctwo społeczne odnosi się do stanu prawnego i psychicznego przeżyć jakie dokonują się u dziecka. Sierotą społeczną jest dziecko, które wychowuje się $\mathrm{w}$ rodzinie pełnej albo posiada jednego z rodziców, ale nie wypełniają oni należycie swoich obowiązków lub misji wobec niego. Ponadto zaniedbują je i są dla niego zagrożeniem psychicznym, moralnym i fizycznym (por. Cudak, 1998, s. 91). Roman Pawłowski i Edward Jundził ukazują czynniki jakie tworzą pustką emocjonalna wokół dziecka:

- w zakresie szerokim - sieroty społeczne to dzieci o subiektywnym i trwałym poczuciu osamotnienia, które mieszkają z rodzicami, są pod ich opieką, ale jest słaba między nimi wieź emocjonalna;

- w zakresie wąskim - odnosi się do dzieci, które zostały pozbawione naturalnego środowiska rodzinnego i nie utrzymują systematycznego kontaktu z rodziną. Rodzice mają ograniczone, bądź nie mają praw do dziecka, a państwo przejmuje obowiązki opiekunów (por. Pawłowska, Jundziłł, 2000, s. 28-33).

Maria Szymborska wyróżniła trzy stopnie sieroctwa społecznego biorąc pod uwagę częstotliwość kontaktów rodziców z dziećmi:

- najwyższy - zachodzi, gdy brak relacji na linii rodzice dziecko, 
- średni - ma miejsce wówczas, gdy kontakt rodziców z dzieckiem nie został jeszcze zerwany, lecz jest on rzadki, niesystematyczny i niewystarczający,

- najniższy - rodzice interesują się dzieckiem, jego potrzebami, choć na co dzień nie ingerują w jego życie (Matyjas, 2006, s. 726).

Andrzej Tynelski zaproponował następujący podział sieroctwa społecznego:

- sieroctwo społeczne prawne - istnieje na skutek orzeczenia sądu, który ograniczył prawa rodziców do dzieci lub ich tego pozbawił,

- sieroctwo społeczne losowe - jest wynikiem jakiegoś zdarzenia losowego, jak choćby śmierć rodziców,

- sieroctwo społeczne, które zaistniało w wyniku nieprawidłowego funkcjonowania lub zaniedbania przez rodziców potrzeb dziecka,

- sieroctwo społeczne emocjonalne, u którego podstaw leży odrzucenie dziecka przez rodziców (tamże, s. 726-727).

Mówiąc o problemie sieroctwa należy podkreślić, że nowe czasy, w których żyje człowiek oraz postęp cywilizacji doprowadziły do powstania tzw. sieroctwa decyzyjnego. Rodzi się ono w wyniku określonych decyzji rodziców, czy organów administracyjnych, np. sądu rodzinnego. Jako przyczyny tego sieroctwa należy wskazać na: kryzys rodziny, jej dezorganizację, rozpad, decyzję kobiety o posiadaniu dziecka bez ojca, decyzję jednego z rodziców o uniemożliwieniu kontaktów z drugim rodzicem, pośrednio migrację rodziców (por. Olearczyk, 2010, s. 109-111).

Można wyróżnić jeszcze sieroctwo jako pewien stan ducha, jaki następuje w wyniku poczucia osamotnienia. Warunkowane może być ono przez: pozbawienie dziecka kontaktów z ojcem, negatywne nastawienie dziecka do ojca przez matkę, zanik kontaktu ojca z dzieckiem poprzez niechęć do matki lub dziecka, zaburzenia relacji wewnątrzrodzinnych, izolowanie się młodego człowieka od społeczeństwa lub jego odrzucenie przez rówieśników (tamże, s. 111).

Inny rodzaj sieroctwa związany jest z działaniami wojennymi, stąd można mówić o sieroctwie wojennym. Taka osoba wymaga szczególnej troski i pomocy poprzez pomoc medyczną, socjalną, wsparcie emocjonalne, rekonstruowanie ról społecznych osieroconego dziecka (por. Theiss, 2012, s. 737).

Szczególny rodzaj sieroctwa związany jest z dziećmi ulicy, stąd nazywa się ono sieroctwo utajone. Dziecko utrzymuje swoich opiekunów, choć samo pozbawione jest ich opieki i samo musi zadbać o siebie i swoje potrzeby. Nic dziwnego, że taki nastolatek często włóczy się i wałęsa po ulicach miasta. Szuka tam wytchnienia, miłości, realizacji siebie. Ulica staje się dla niego środowiskiem życia, miejscem nauki, wychowania i socjalizacji (por. Szymborska, 1969, s. 13-15).

Inny typ sieroctwa polega na braku identyfikacji z płcią. Polega to na braku identyfikacji biologicznej, zaburzeniach rozwojowych i psychicznych oraz braku akceptacji własnej płciowości (por. Olearczyk, 2010, s. 113). 
W literaturze pojawił się jeszcze termin związany z migracją rodzin i jej poszczególnych członków, czyli migracja zarobkowa. Związana jest z rozłączaniem się rodzin w celu poprawy swojego statusu społecznego i ekonomicznego. Biorąc to pod uwagę Witold Danielewicz ze względu na nieobecność rodziców wyodrębnia następujące typy rodzin:

- rodziny czasowo niepełne, ponieważ rodzice przebywają za granicą w celach zarobkowych,

- rodziny czasowo niepełne z powodu zarobkowego pobytu obojga rodziców za granicą równocześnie,

- rodziny czasowo niepełne, ponieważ rodzice zamiennie wyjeżdżają za granicę,

- rodziny stale niepełne jeszcze przed wyjazdem rodzica za granicę,

- rodziny niepełne wskutek rozwodu lub porzucenia w trakcie migracji zagranicznej (tamże, s. 111).

Mając na uwadze zagadnienie sieroctwa można podjąć próbę zdefiniowania kim jest eurosierota i jak olbrzymi jest problemu eurosieroctwa. Eurosierota to dziecko, które jest wychowywane przez jednego rodzica, ponieważ drugi wyjechał za granicę w celach zarobkowych. Eurosieroctwo to fakt nieposiadania przez niepełnoletniego obojga rodziców lub jednego, którzy wyjechali z kraju w poszukiwaniu pracy (por. Kozak, 2010, s. 113). Według Rzecznika Praw Dziecka w ujęciu psychologicznym eurosieroctwo to „zjawisko pozostawienia w kraju dzieci przez rodziców wyjeżdżających za granicę (...), zdaniem, dzieci pozbawionego stałego kontaktu nawet z jednym z rodziców, czują się jak sieroty" (Biuletyn Informacyjny Rzecznika Praw Dziecka, 2008, s. 2-4). Stanisław Trusz dodaje, że eurosierotą można nazwać dziecko, które jest pozbawione kontaktu z rodzicem lub rodzicami, którzy wyjechali z kraju i nie realizują obowiązków rodzicielskich jakie wynikają z ich roli (por. Trusz, Kwiecień, 2012, s. 40).

Z kolei B. Walczak zwraca uwagę na skutki psychiczne, jakie dotykają dzieci, które żyją w niepełnej rodzinie, ponieważ jedno lub obydwoje rodziców wyjechali z kraju, aby podnieść standard życia lub osiągnąć minimum pozwalające na egzystencję rodziny. Ponadto akcentuje, że ta rozłąka z dziećmi jest decyzją zupełnie świadomą i nie musi prowadzić do rozpadu więzi rodzinnych. Przyczyn rozpadu należy szukać we wcześniejszych sytuacjach, jak choćby kłótnie, nieporozumienia, destrukcyjne działania wobec siebie i całej rodziny (por. Walczak, 2008, s. 10).

\section{Skutki eurosieroctwa w aspekcie osobowościowym}

Pierwszym uczuciem, jakie przeżywa dziecko, którego przynajmniej jeden z rodziców emigruje za granicę, jest jego samotność. W każdej definicji pojęcia samotność występują trzy wspólne cechy: 
- braki w kontaktach i stosunkach międzyludzkich,

- doświadczenie subiektywne,

- samotność ma w sobie wartości stresujące i nieprzyjemne (por. Kozak, 2010, s. 140).

J. Gajda wyróżnia następujące rodzaje samotności:

- samotność społeczną całkowitą i częściową (charakteryzuje się brakiem więzi z innymi ludźmi),

- samotność z wyboru (występuje w życiu klasztornym, zakonnym i własnej osobistej decyzji),

- samotność niechciana (spowodowana przebywaniem dziecka w domu dziecka, czy zgonem współmałżonka) (por. Gajda, 1987, s. 86).

Osamotnienie dziecka jest związane z samotnością, izolacją społeczną oraz brakiem i zakłóceniem relacji międzyludzkich. Nastolatek zamyka się w swoim świecie i przeżywa na swój sposób własne problemy i trudności. Samotność może mieć u niego wymiar społeczny, jako pewne odosobnienie od rówieśników, ale też psychiczny. Wiąże się ono z brakiem jakichkolwiek wartości, symboli, wzorów oraz z pewnym chaosem w życiu wewnętrznym (por. Gadacz, 1995, s. 17). Na powstanie uczucia samotności u dziecka ma wpływ to, czy czuje się ono zagrożone ze strony innych ludzi i czy ma miejsce u niego pojawienie się pewnej blokady emocjonalnej. Uwidacznia się ona w tym, gdy młody człowiek nie okazuje wobec innych uczuć i emocji. Ponadto w jego działaniu uwidacznia się depresja, smutek, myśli samobójcze oraz pustka emocjonalna i egzystencjalna (por. Izdebska, 2004, s. 59).

Z samotnością dziecka powiązany jest jego lęk. Łączy on w sobie niepokój, napięcie, bezradność i brak pewności siebie. Pojawia się wówczas, gdy nastolatek nie ma poczucia bezpieczeństwa. Obawia się, że pozostawiony sam sobie nie poradzi sobie w nowej sytuacji i roli. Każdy nadchodzący dzień napawa go strachem i przerażeniem. Przekłada się to na jego silną nieśmiałość, brak aktywności w poznawaniu otaczającego świata, biernością i trudnościami w nauce. Dziecko wyłącza się z życia publicznego i unika jakichkolwiek kontaktów ze światem. Często podejmuje irracjonalne działania, którym towarzyszy wzrost agresji (por. Fidelus, 2008, s. 39-40). W rodzinach emigrujących za granicę bardzo często dochodzi wskutek rozłąki rodziców do rozwodu. Skutki takiego ich czynu odbijają się na życiu dziecka. Staje się ono lękliwe, płaczliwe, szuka bliskości z innymi dorosłymi, wzrasta jego agresywność, pojawiają się problemy społeczne i szkolne. Dziecko staje się uczestnikiem kłótni rodziców, często o sprawy materialne i kto będzie jego prawnym opiekunem. Ponadto jest wciągane w konflikty między dorosłymi, którzy chcą wywrzeć na nim presję i szukają w nim sprzymierzeńca do walki z drugim opiekunem. To rodzi w dziecku poczucie samotności i bezradności (por. Jade, 2007, s. 45-55). 
Opiekunowie dziecka pracując za granicą nie myślą o powiększeniu rodziny. Nic dziwnego, że dziecko wówczas staje się jedynakiem. Poświęca się mu wiele czasu i jest ono obiektem szczególnego zainteresowania i nadmiernej troski. Niestety, wielokrotnie jest ono zbyt nadmiernie chronione przed kontaktami z innymi rówieśnikami i dlatego samo szuka kontaktu z dorosłymi ludźmi, ponieważ ma trudności w nawiązaniu kontaktów z rówieśnikami (por. Zborowski, 1979, s. 390).

Samotność rodzi u dziecka poczucie krzywdy wobec niego. Syndrom braku czasu dla nastolatka, wydłużający się czas pracy, nieobecność rodziców na ważnych dla dziecka wydarzeniach, jak jego urodziny, imieniny czy np. odbiór świadectwa szkolnego prowadzą do dezorganizacji u niego pojęcia wartości (por. Izdebska, 2004, s. 60).

Brak jednego z rodziców w wychowywaniu dziecka prowadzi do zaniku w jego życiu wzoru do naśladowania. Ojca nie zastąpi matka, a jej funkcji nie zastąpi ojciec, nawet gdyby bardzo się starali. „Rola ojca jako wzoru osobowego w uczeniu się, szczególnie u chłopców, jest niezwykle ważna. Wzrastając w rodzinie pełnej, mając oba wzory osobowe rodziców, dziecko może zdobywać przygotowanie do późniejszych ról społecznych jak: rola kobiety i mężczyzny, żony i męża, czy matki i ojca. Obecność dwu wzorów ułatwia przyswojenie typu zachowań odpowiadającego płci, gdyż właśnie rodzice poprzez swoją obecność dostarczają dziecku wzorów zachowania" (Jarosz, 1987, s. 85). Dziecko, które jest wychowywane przez matkę, ma problem w życiu z nawiązywaniem relacji interpersonalnych z innymi ludźmi. Ponadto dziecko odrzucone przez ojca i niedopilnowane przez niego staje się ponure, posępne, nieśmiałe, bojaźliwe i nieufne. Ojciec postrzegany jest jako osoba, która rzadziej kocha, nie rozumie nastolatka, a w dłuższej konsekwencji zapomina zupełnie o nim jako swoim rodzicu (Brągiel, 1990, s. 94). Z kolei jeśli funkcje matki, która wyemigrowała za granicę, przejmuje ojciec, to dziecko pozbawione jej opieki staje się bardziej uboższe i pozbawione uczuć. Przynosi to negatywne skutki i konsekwencje dla jego dalszego rozwoju i egzystencji w społeczeństwie (Mościcka, 1992, s. 32). Barbara Zięba akcentuje, że „dzieci wywodzące się z rodzin niepełnych częściej niż inne będą realizowały swe role w sposób niepełnowartościowy i cząstkowy, będą posiadały gorszą orientację w rolach społecznych, co wyrażać się będzie niższym poziomem ich zaangażowania w sprawy domu i rodziny oraz wpływać może na zakres ich zaangażowania i zdolności przystosowania funkcjonalnego w środowiskach pozarodzinnych" (Kukołowicz, 1999, s. 61).

Z czasem dziecko zaczyna zatracać, kim i po co jest ojciec, matka i jakie mają spełniać wobec niego funkcje. Takie pojęcia i wartości, jak dom, rodzina z niczym mu się nie kojarzą i nie mają żadnego odniesienia. Dlatego nastolatek szuka wspólnoty u ludzi, którzy będą wpływać na jego osobowość. Dla grupy, w której będzie czuł się bezpiecznie, jest gotowy zrobić wszystko, poświęcić się dla jej dobra, byleby być w niej zaakceptowanym, docenionym i potrzebnym (por. Galińska, 2013, s. 6). 


\section{Skutki eurosieroctwa w wymiarze społecznym}

Rodzice emigrując do innych krajów często nie zdają sobie sprawy ze zjawiska rozpadu wspólnoty rodzinnej. Nic dziwnego, że jej miejsce i obowiązki chce zająć sekta. Sukces sekty wiąże się z protestem jej członków wobec społeczeństwa i świata. Kiedy rodzina nie daje nastolatkowi poczucia bezpieczeństwa, wówczas człowiek szuka swojej realizacji i chęci poczucia przynależności w grupie nieformalnej. Często jest to sekta satanistyczna, gdzie w destrukcyjnej jej działalności dziecko odnajduje swoje szczęście. Lęk przed niepewną przyszłością i brak spełniania obowiązków przez rodziców przekonują dziecko do zaufania tzw. nowej rodzinie, jaką jest sekta. W niej odnajduje autorytet, jakim jest jej przywódca. $\mathrm{Z}$ jego nauki i z funkcjonowania całej grupy wypływa poczucie spokoju, radości i miłości (por. Pikuła, 2009, s. 111-112). Sekta daje młodemu człowiekowi możliwość aktywności i braku anonimowości. W niej realizuje swoje marzenia i rozwija zdolności. Wszyscy się nim interesują i nie jest porzucony. Ponadto dostrzega, że w grupę wnosi swoje zaangażowanie, a ona daje mu możliwości spełnienia się. Nie jest $\mathrm{w}$ niej ignorowany i niedoceniany. Wreszcie sekta daje pozory zaspokajania potrzeb emocjonalnych, a tak naprawdę prowadzi do zniewolenia, manipulacji i ogłupienia nastolatka (por. Posacki, 2004, s. 31). Staje się ona często niejako drugim domem dla dziecka. W niej ma ono zapewnioną potrzebę miłości. Cała grupa potrafi wytworzyć prawdziwą, kochającą się wspólnotę. Przekonuje, stosując czynniki manipulacji, że tylko w niej każdy nowy adept odnajdzie swoją atrakcyjność, zrozumienie i wzajemną miłość. Z czasem wpływ sekty jest tak wielki na młodego człowieka, że decyduje się on na rozluźnienie więzi rodzinnych, a w dalszej konsekwencji na całkowite porzucenie swojej rodziny i bliskich (por. Pikuła, 2009, s. 122). Dziecko w sekcie wykorzystywane jest jako tania siła robocza, a niekiedy wspomaga swoją obecnością pracę dorosłych misjonarzy. Zmusza się je do czynów niemoralnych, jak kradzież, bezczeszczenie świętych miejsc, kłamstwa czy zabójstwa (por. Steffon, 1993, s. 118). Sekta zachęca do autokreacji siebie i swoich zdolności. W tym celu proponuje:

- przyjmowanie środków uzależniających i odurzających,

- swawolną seksualność,

- tworzenie charakterystycznej subkultury młodzieżowej o charakterze patologicznym, która będzie zagrażała porządkowi i ładowi moralnemu (por. Zwoliński, 2012, s. 302).

Działalność takiej grupy destrukcyjnej w życiu dziecka przynosi ogromne szkody w postaci negatywnego poglądu na działalność szkoły, nauki, pracy edukacyjnej, zniechęcenie do pracy, rozbicie środowiska domowego i szkolnego, lekceważący stosunek do ludzi (tamże, s. 309). 
Konsekwencją eurosieroctwa jest zaniedbanie przez dziecko obowiązku szkolnego. Stanisław Kozak stwierdza, że „efektem eurosieroctwa i braku opieki jest wagarowanie, opuszczanie się dzieci w nauce, porzucanie szkoły (...)” (Kozak, 2010, s. 116). Szkoła, która pełni funkcje edukacyjną, ale i wychowawczą, nie jest przygotowana do nowych wyzwań związanych z migracją rodziców, którzy zostawili w kraju swoje dziecko. Nastolatek, który poszukuje pomocy u pedagoga szkolnego, nie uzyskuje żadnego wsparcia u niego, ponieważ nie widzi on jakiegokolwiek problemu dla nastolatka, jaki powstaje w wyniku wyjazdu rodziców za granicę. Ponadto w placówkach edukacyjnych w dzisiejszych czasach do rzadkości należy obecność pedagoga, w związku z oszczędnościami budżetowymi. Dziecko pozbawione opieki pedagogicznej w szkole czuje się zbuntowane i negatywnie nastawione do społeczności szkolnej. Może to skutkować pojawieniem się zachowań przestępczych wobec kolegów i nauczycieli. Często do nich prowadzą rodzice, którzy przed swoją emigracją nie poinformowali o tym organów szkoły. Nie uwrażliwili dyrektora szkoły i wychowawcy klasy, że należy zwrócić szczególną uwagę na ich dziecko, które przez określony czas będzie pozbawione obecności jednego bądź dwóch rodziców. Ponadto nie nakreślili problemów dziecka i jego wewnętrznej struktury emocjonalnej (por. Paszkiewicz, 2013, s. 29-30).

Istotnym czynnikiem wpływającym na życie człowieka jest kultura. Obyczaje, wierzenia, kształtowanie poglądów dziecka od chwili jego narodzenia istotnie rzutują na jego życie i rozwój w społeczeństwie. Dzięki rodzicom możliwe jest nie tylko ich zachowanie, ale także nieustanne krzewienie i ich przypominanie. To prowadzi do pewnej harmonii i dbania o patriotyzm i miłość do ojczyzny. Te wszystkie wartości zaczynają przeżywać kryzys, gdy rozpoczyna się emigracja rodziców za granicę. Nie ma kto zwracać uwagi dziecku na wartości kultury i pielęgnowanie obyczajów i tradycji. W młodym człowieku zaczyna to szybko obumierać i traci swoją wartość (por. Napora, 2009, s. 61).

Dziecko pozbawione jednego lub dwojga rodziców czuje się samotne, oszukane, pozbawione bezpieczeństwa i dlatego szuka zaspokojenia własnych potrzeb. Takim miejscem niezwykle specyficznym staje się ulica i działające na niej różnego rodzaju gangi i grupy nieformalne o specyfice przestępczej. Ulica wydaje się dla nastolatka miejscem bezpieczniejszym niż rodzinny dom, który jest pusty i zimny emocjonalnie. Uciekając z domu nastolatek pragnie zwrócić uwagę rodziców na swoje problemy i zasygnalizować własną krzywdę, samotność i lęk. Egzystując w środowisku ulicy musi podporządkować się zasadom i regułom tam panującym. Nic dziwnego, że jest kimś w rodzaju marionetki. Ulica jest nową szkołą życia i uczy sposobów przetrwania w niesprzyjających i trudnych okolicznościach. Nawet jeśli zajmuje niską pozycję społeczną w grupie, akceptuje to, ponieważ po raz kolejny nie chce przeżywać traumy odrzucenia i izolacji i zniszczenia własnej osobowości (por. Fidelus, 2008, s. 42). 


\section{Skutki eurosieroctwa w aspekcie moralnym}

Dziecko pozbawione uczuć i miłości rodzicielskiej próbuje wypełnić sobie zaistniałą pustkę i samotność. Nic dziwnego, że powstają różnego rodzaju czynności łamiące przyjęte normy moralne, a w dalszej konsekwencji i stanowione prawo. Jednym z takich wykroczeń moralnych i prawnych staje się pornografia. Znieczula ona odbiorcę na kolejne bodźce, jakie docierają do niego, stępia wrażliwość etyczną i oswaja z bezwstydem. Działa na świadome i nieświadome procesy fizjologiczne, umysłowe, emocjonalne, motywacyjne i drążeniowe. W pornografii człowiek jest tylko odbiorcą lub nadawcą sygnałów seksualnych. To wszystko wpływa na niszczenie procesu przygotowania do życia w rodzinie. Dalej prowadzi to do erotyzacji psychiki dziecka oraz do przedwczesnego rozbudzenia seksualnego (por. Zwoliński, 2012, s. 227).

Inną formą szukania miłości i walki o swoją tożsamość jest zjawisko prostytucji dziecięcej. Wyciska ona na dziecku piętno trwałego urazu psychicznego, pozbawia równowagi psychicznej i dezorganizuje jego całe życie psychiczne. Pojawiają się powracające nocą koszmary, negatywne emocje, nadmierna wrażliwość, trudności w koncentracji, brak perspektyw życiowych, zaniżona samoocena. Można mówić o całkowitej ruinie duchowej dziecka i głębokim zranieniu psychicznym (por. Pawlak-Jordan, Szulik, 2006, s. 91-96).

Wraz z prostytucją i pornografią idzie w parze molestowanie dzieci rodziców emigrujących za granicę. Przejawia się ono w gwałtach, pedofilii czy kazirodztwie. Krzywdy jakie w tych aspektach dotykają dziecko zawsze niszczą jego dobro, zaspokajają wynaturzenia ludzi dorosłych i wskazują na problemy konsumpcyjnego i egoistycznego życia (por. Zwoliński, 2012, s. 251).

Wszystkie powyższe zjawiska wskazują na przemoc, która wobec dzieci może przybierać różne formy: fizyczną, psychiczną, werbalną i seksualną. Prowadzi to do zakłócenia realizacji takich funkcji, jak emocjonalna, opiekuńcza, wychowawcza, towarzysko-rekreacyjna, ekonomiczna i w końcu do braku poczucia bezpieczeństwa. Dziecko odczuwa ból psychiczny, opuszczenie przez najbliższych, poczucie zagrożenia, zagubienie, brak miłości, zastraszenie, lęki, objawy nerwicowe (por. Matyjas, 2008, s. 35).

Inny skutek eurosieroctwa dziecka związany jest ze wzrostem u niego zjawiska agresji. Według J. Dollarda i N.M. Millera jest to zawsze poprzedzone frustracją, która rodzi zachowanie agresywne. Może ono przejawiać się w izolowaniu się, demonstracyjnym okazywaniu swego niezadowolenia, atakiem fizycznym lub słownym wobec drugiej osoby (Olearczyk, 2010, s. 200-201).

Do zagrożeń dziecka jakie pojawiają się w wyniku emigracji rodziców należy zaliczyć szerzące się uzależnienia. Głównie związane jest to z ucieczką w świat al- 
koholu i narkotyków, w tym bardzo modnych dopalaczy. Problem alkoholu może w rodzinie pojawić się w wyniku poprawy statusu ekonomicznego, ponieważ trzeba uczcić poprzez libacje alkoholowe nową sytuację społeczną. To jest szczególnie groźne dla biosocjokulturalnego rozwoju dziecka (por. Matyjas, 2006, s. 34-35).

Nastolatek pozbawiony opieki rodzicielskiej sam organizuje sobie zajęcia i zagospodarowanie czasu wolnego. Czyni to często poprzez mediatyzację i oglądanie w telewizji i Internecie różnych programów, które wpływają na jego psychikę i kształtowanie jego osobowości. Dziecko oglądając programy, w których dominuje przemoc, samo zaczyna wykazywać tendencje agresywne. Gry komputerowe i rzeczywistość wirtualna powodują dezorganizację całego dnia i doprowadzają do nałogu netoholizmu (tamże, s. 34).

Bardzo często wypełnieniem tych wszystkich skutków emigracji rodziców za granicę i pozostawienia dziecka w kraju jest jego samobójstwo. Kojarzy się ono z ogromnym ciężarem nie do uniesienia, z pustką życiową i całkowitą beznadzieją oraz pojawiającą się depresją i samotnością. $\mathrm{O}$ wymiarze śmierci i jej popełnieniu dziecko dowiaduje się z bajek, gier komputerowych i filmów. Fakt samodestrukcji jest niezwykle bolesny dla całego społeczeństwa, szczególnie dla najbliższej rodziny. Wielu dorosłych oskarża się wówczas o nieumiejętne odczytywanie znaków, jakie wysyłał nastolatek, nadmierną bierność i swoją winę (por. Rachid Chehab, 2009, s. 13).

\section{Zakończenie}

Dzisiejsza rodzina wskutek wielu problemów, zwłaszcza ekonomicznych, podejmuje emigrację. Chce w ten sposób poprawić swój byt osobowościowy, ekonomiczny i społeczny. Niestety, ludzie dorośli emigrując za granicę, nie biorą pod uwagę konsekwencji jakie za tym idą w odniesieniu do pozostawionego w kraju dziecka. W dłuższej perspektywie rozłąki u niego pojawia się wiele problemów rzutujących na jego życie emocjonalne, osobowe, społeczne i moralne. Pozostawiony sam sobie szuka możliwości zaspokojenia pustki, jaka go dotknęła. Nic dziwnego, że zapełnia ją poprzez szukanie ludzi i nieformalnych grup, które zajmą się jego uczuciami i potrzebami. Ucieka w świat uzależnień, przemocy, agresji i konfliktu z prawem. Gdy już nie umie sobie poradzić z narastającymi problemami osobistymi i w wyniku konfliktu ze stanowionym prawem, popełnia samobójstwo. Dopiero taki akt otwiera oczy rodzicom, którzy przekonują się, jak wielką krzywdę wyrządzili swemu dziecku, choć często jest już za późno, aby ją naprawić. Dlatego istotne jest podjęcie działań, które zwrócą uwagę na ten problem i będą próbowały go rozwiązać. Ważne jest uświadamianie rodzicom skutków, jakie niesie ich wyjazd za granicę. 
Być może urzędy pracy powinny uświadamiać dorosłym, jakie problemy mogą się pojawić z ich dziećmi, gdy podejmą pracę poza granicami Polski. Również szkoła powinna uwrażliwiać rodziców i dzieci na nowe zjawisko sieroctwa powstającego na skutek emigracji ludzi dorosłych.

\section{Bibliografia}

Biuletyn Informacyjny Rzecznika Praw Dziecka. W: Informacje dla rodziców podejmujacych prace poza granicami kraju, 1-2(2008).

Brągiel J. (1990). Wychowanie w rodzinie niepetnej. Opole: Wyższa Szkoła Pedagogiczna.

Cudak H. (1998). Zaspokojenie potrzeb psychicznych $w$ rodzinie, a sieroctwo duchowe dzieci. W: T. Sołtysiak (red.), Sieroctwo spoteczne, przyczyny, skutki i sposoby jego zapobiegania w aktualnej rzeczywistości kraju. Włocławek: Wyższa Szkoła Humanistyczna.

Czeredrecka B. (1998). Potrzeby psychiczne sierot spotecznych. Warszawa: Wydawnictwo Naukowe UW.

Fidelus A. (2008). Gdy rodzice emigruja. „Nowa Szkoła”, nr 6(64).

Gadacz T. (1995). O samotności - o spotkaniu, Kraków: Wydawnictwo Znak.

Gajda J. (1987). Samotność i kultura. Warszawa: Wyd. UW.

Galińska I. (2013). Sieroty ekonomiczne. „Niedziela”, 22-23.

Jade W. (2007). Jak uchronić dziecko przed skutkami rozwodu rodziców. Poradnik dla rodziców. Kraków: Wyd. WAM.

Jarosz M. (1987). Dezorganizacja w rodzinie i spoteczeństwie. Warszawa: Państwowe Wydawnictwo Ekonomiczne.

Izdebska J. (2004). Dziecko osamotnione w rodzinie. Białystok: Wydawnictwo Uniwersyteckie.

Kawula S., Bragiel J., Janke A. (1995). Pedagogika rodziny. Obszary i panorama problematyki. Toruń: Wydawnictwo Adam Marszałek.

Kozak S. (2010). Patologia eurosieroctwa w Polsce. Skutki migracji zarobkowej dla dzieci i ich rodzin. Warszawa: Wydawnictwo Difin.

Kukołowicz T. (1999). Sytuacja wychowawcza w nowych kategoriach rodzin w okresie transformacji. W: M. Ziemska (red.), Rodzina wspótczesna. Warszawa: Wyd. Uniwersytetu Warszawskiego.

Matyjas B. (2008). Oblicza dzieciństwa we wspótczesnych rodzinach polskich. W: B. Muchacka, K. Kraszewski (red.), Dziecko w świecie wspótczesnym. Kraków: Wydawnictwo Impuls. 
Matyjas B. (2006). Sieroctwo. W: T. Pilch (red.), Encyklopedia pedagogiczna XXI wieku, T. V. Warszawa: Wydawnictwo Akademickie Żak.

Mościcka L. (1992). Spoteczne skutki dezorganizacji życia rodzinnego. Wrocław: Wydawnictwo Uniwersytetu Wrocławskiego.

Napora E. (2009). Niedobór kontaktu z rodzicami jednq z przyczyn zaburzonego funkcjonowania dziecka. W: M. Janukowicz (red.), Smak emigracji. Dramaty dzieci. Kraków: Wydawnictwo Scriptum.

Olearczyk T.E. (2010). Sieroctwo i osamotnienie. Pedagogiczne problemy kryzysu wspótczesnej rodziny. Kraków: Wydawnictwo Impuls.

Paszkiewicz A. (2013). Uczeń, którego rodzice pracuja za granica. „Problemy Opiekuńczo-Wychowawcze", nr 11(524).

Pawlak-Jordan B., Szulik M. (2006). Uraz psychiczny u dziewcząt zmuszanych do prostytucji. „Dziecko Krzywdzone”, nr 16.

Pawłowska R., Jundziłł E. (2000). Pedagogika cztowieka samotnego. Gdańsk: Wyd. Gdańska Wyższa Szkoła Humanstyczna.

Posacki A. (2004). Sekty. Częstochowa: Wydawnictwo Misjonarzy Krwi Chrystusa. Pikuła N. (2009). Emigracja zarobkowa rodziców przestanka odchodzenia mtodzieży do sekt. W: M. Janukowicz (red.), Smak emigracji. Dramaty dzieci. Kraków: Wydawnictwo Scriptum.

Rachid Chehab M. (2009). Caty Internet umiera z nami. „Przekrój”, nr 43.

Steffon J.J. (1993). Satanizm jako ucieczka w absurd. Kraków: Wydawnictwo WAM.

Szymborska A. (1969). Sieroctwo spoteczne. Warszawa: Wydawnictwo Pedagogiczne.

Theiss W. (2012). Sieroctwo wojenne. W: T. Pilch (red.), Encyklopedia pedagogiczna XXI wieku, T. V. Warszawa: Wydawnictwo Akademickie Żak.

Trusz S., Kwiecień M. (2012). Spoteczne piętno eurosieroctwa. Warszawa: Wydawnictwo Difin.

Walczak B. (2008). Migracje poakcesyjne w perspektywie ucznia. Wstępna diagnoza spotecznych i pedagogicznych skutków euro-emigracji rodziców i opiekunów. Warszawa: Wydawnictwo Uniwersytetu Warszawskiego.

Zborowski J. (1979). Problem jedynactwa w rodzinie. W: M. Ziemska (red.), Rodzina i dziecko. Warszawa: Wydawnictwo Pedagogiczne.

Zwoliński A. (2012). Krzywdzone dzieci. Zagrożenie wspótczesnego dzieciństwa. Kraków: Wydawnictwo WAM. 
The effect of orphanhood in the social, moral and personality dimensions as a result of parents' emigration

\begin{abstract}
Nowadays it is emphasized that the human does not have any barriers to moving from place to place. People often emigrate from one country to another for economic reason. They want to acquire quickly the material resources and dower own family. Unfortunately, many times he does not recognize that his departure has certain consequences. In a special way they affect the child, who is referred to as the euro-orphan. When they are left alone and even abandoned by their guardians, they seek to fill the void of parental love in their own way. They find it in many addictions and sexual deviations.
\end{abstract}

Keywords: orphan, euro-orphan, child, family 